\title{
Management Experience in Fighting with COVID-19 and Other Aspects of Counteraction
}

\author{
Evgeniy Bryndin ${ }^{1}$, Irina Bryndina ${ }^{2}$ \\ ${ }^{1}$ Research Centre "Nature Informatic" of Technological Platform Future Medicine, Novosibirsk, Russia \\ ${ }^{2}$ Pediatric Faculty of Novosibirsk State Medical University, Novosibirsk, Russia
}

Email address:

bryndin@ngs.ru (E. Bryndin), iriska26@ngs.ru (I. Bryndina)

\section{To cite this article:}

Evgeniy Bryndin, Irina Bryndina. Management Experience in Fighting with COVID-19 and Other Aspects of Counteraction. American Journal of Management Science and Engineering. Vol. 5, No. 2, 2020, pp. 19-23. doi: 10.11648/j.ajmse.20200502.11

Received: May 31, 2020; Accepted: June 11, 2020; Published: June 23, 2020

\begin{abstract}
Testing is central, early detection of the virus minimizes its further spread and allows rapid treatment of the sick said the head of the South Korean Ministry of Foreign Affairs Kang Gyung Hua. He believes effective management and tests are key to our very low mortality rate. South Korea's health and public administration system was able to quickly protect the population from COVID-19 without the imposition of emergency measures. The adviser to the Swedish government and the Secretary-General of the World Health Organization, Yuhan Gizeke, told the RBC in an interview on May 5, 2020 that the authorities of the country relied on two measures in the fight against coronavirus whose benefit has scientific justification. First, we need to wash our hands, which we've known for 150 years. Second, social distance should be respected, that is, not to get too close to other people. Until May 5, 2020, Sweden recorded only 23216 cases of coronavirus infection. Developed countries have begun to develop a vaccine to combat COVID-19. Any vaccine contains a specific antigen - a protein that provokes antibody production - immune response. In the body antigen is met with specially adapted cells - macrophages. They get acquainted with the antigen and read information from it, - explains Alimbarov. - The obtained information they transmit to $\mathrm{T}$ lymphocytes, which in turn begin to change, and among them appear cells that will also participate in the immune process. $\mathrm{T}$ cells transmit information to B lymphocytes, which are converted into plasma cells capable of producing antibodies. Part of B lymphocytes is converted into memory cells. They store information about the antigen and, upon repeated encounter with a similar antigen, trigger an immune response (antibody formation) in a shorter time frame. The vaccine can be live (weakened virus), inactivated (dead virus) or vector - that's what the coronavirus vaccine will be. It contains a human-harmless adenovirus whose DNA contains the coronavirus gene. The adenovirus is then used as a delivery container.
\end{abstract}

Keywords: Covid-19, To Work Quickly, To Do Many Tests, Biogenic Health Maintenance in Ontogenesis

\section{Introduction}

An outbreak of COVID-19 disease caused by SARS-CoV2 virus occurred in Wuhan, China, in late December 2019. Outside China, the disease has been diagnosed in patients in more than 190 countries. On March 11, the World Health Organization (WHO) declared a coronavirus pandemic. At the beginning of the spread of the infection, South Korea became one of the major hotbeds of the disease outside China. South Korea has proved by its example that the virus can be contained without stopping the economy.

A week after identifying the first infected, on January 27, South Korean authorities met with representatives of more than 20 medical companies and urged them to immediately begin developing tests for mass production. The first set for the test, made by Kogene Biotech Co., received government approval on February 4. At that time, there were only 16 cases of virus COVID-19 in the country. Delivery of tests began three days later. To relieve the increased burden on hospitals, 633 centres have been set up in the country, designed for coronavirus testing only, including 50 stations in parking lots in which people can pass the test without leaving their cars. There they fill out the questionnaire, they measure the temperature and take a smear from the throat. The process takes about 10 minutes. Samples that are stored in sealed containers at $4^{\circ} \mathrm{C}$ are delivered in vans to 118 laboratories. Test results are reported within hours.

Unfortunately, many countries at that time showed little 
vision, willingness and managerial will to protect the population from COVID-19. This required heavy costs, emergency measures and resulted in heavy casualties.

The introduction and management of the COVID-19 pandemic in Russia began with delay and not very professionally. Academician of the Russian Academy of Sciences, Professor, Chief Freelance Epidemiologist of the Ministry of Health of the Russian Federation, Nikolai Brico in an interview with the Russian newspaper on May 4, 2020 pointed out that the most active spread of infection occurs in close contacts in the family, in places of large population of people and organized collectives with long stay of people (military collectives, educational institutions, homes for the elderly and other public places. For example, in Cherepanov district of Novosibirsk after the identification of the patient with coronavirus tested the whole circle of her contacts and registered 11 more sick. Regional medicine tested infected coronavirus with symptoms, and a month later began testing not only the sick, but their surroundings. Which allowed to identify the number of people without symptoms infected with coronavirus.

\section{Spiritual and Naturalistic Aspects of the Safety of the Population from COVID-19}

Autonomous contactless infections of people by coronavirus in different countries at the same time, according to many scientists and the WHO, suggest its natural origin. According to some experts, coronavirus originated in bats. Coronavirus reproduction occurred within the cells of organisms of various animals. It is likely that migratory feathers became global intermediate sources of infection spread in different countries when coronavirus began to be transmitted to people from them. Then the human population became the source of the pandemic by the spread of coronavirus. The carriers of it were asymptomatic citizens.

According to spiritual laws, the cause of COVID-19 is the spiritual state of society. The spiritual level of humanity is falling. Harmful passions take a person away from normal life. The pernicious passion of one person breeds it in other people. The accumulated harmful passions of mankind under spiritual laws in 2020 were the cause of the global coronavirus. The creator made people free to improve life according to spiritual laws. Religious denominations must teach their people to live by them. For example, populated India has a very low infection rate.

COVID-19 suspended the destructive life of mankind and spread people around their corners to think about their way of life and change it to spiritual healthy life. Spiritual processes are also important during the pandemic. A healthy spiritual lifestyle increases the immunity of the body.

Two approaches are formed to treat citizens infected with coronavirus COVID-19, first, functional immunological, and, second, structural genetic. As part of the scientific study, the dynamics of immunological indicators in patients of different ages who have suffered pneumonia caused by COVID-19 are studied. The results of the study reveal indicators indicating the presence of "immune protection" (and the degree of its expression) against COVID-19. There is also a period of time through which "immune protection" is formed and how long it exists in case of contact with COVID-19. On the basis of the identified indicators vaccines for protection against coronavirus COVID-19, as well as drugs for immunityenhancing treatment are developed. Research by Chinese scientists shows that antibodies (immunity) are poorly produced in the light stage of disease. A mild patient is cured by interferons that the body produces. Only antibodies (immunity) are produced in severe form.

Russian scientists managed to decrypt the full COVID-19 genome. It will also help in the development of vaccine and antiviral drugs. And also - the origin and mutations of the virus will no longer be a mystery. This makes it possible to observe how the agent changes. Experts from South Korea were able to determine the life cycle of the virus. This helped them develop methods to combat it.

In Novosibirsk center of virology "Vector" managed to photograph COVID-19. The size is about 100 nanometers, which is billions of dollars of a meter. Around the round spot of the crown, thanks to which the virus got its name. Masks are weakly protected during dialogue at close range.

The genome of the virus aims to constantly deceive the immune system. Coronavirus can affect the lungs of even those people in whom the disease flows without symptoms. Scientists have found that genes of the human immune system affect the course and response to the treatment of coronavirus infection. This discovery will allow the release of genetic Covid tests and in the future "targeting" the use of Covid-19 vaccines. The discovery of Russian scientists will allow to determine the tactics of treatment and what vaccine to use. Scientists have found that only 30 percent of patients who have suffered from COVID-19 have blood serum suitable for the treatment of seriously ill patients.

In some patients, the development of acute respiratory syndrome caused by a new type of coronavirus causes complications of internal organs. Experts at the Center for Reproductive Medicine at Tunji Hospital in Hong Kong, as in Singapore, found that coronavirus of a new type can lead to infertility in men who overburdened coronavirus COVID19. The virus continues to be actively investigated by all laboratories and scientists in the world, and a complete list of all COVID-19 of coronavirus has yet to be established by scientists.

Scientists from the American biopharmatology company Sorrento Therapeutics found an antibody capable of completely blocking coronavirus. The company's specialists investigated billions of antibodies, hundreds of which were capable of affecting coronavirus. Scientists have studied them and found that one of them may be STI-1499 to protect human cells by a hundred percent from SARS-CoV-2 infection. The STI-1499 completely neutralized the infectious properties of the virus at a very low dose of antibodies, which makes it the first candidate for further 
testing and research," - noted in the release of the company. As explained in Sorrento Therapeutics, the principle of the antibody is that it "envelops" the virus and removes it from the body within four days.

Employees of the National Research Center for Epidemiology and Microbiology named after Gamalei of the Ministry of Health of the Russian Federation tested their vector vaccine against COVID-19. The test was successful: immunity is there, no negative effects were found, said Interfax director of the center academician Alexander Ginzburg on May 22, 2020.

\section{Spiritual-naturalistic Approach to Health and Healthy Lifestyle}

During self-isolation to maintain health it is necessary to master and lead a healthy lifestyle [1-16].

The medical community has developed different approaches to the concept of health: hygienic, adaptive, genetic, donosological, prosperous (WHO), equilibrium, physiological, well-being, viable, self-regulating, endoecological, resonance, spiritual, naturalistic and combined approaches. The authors propose a spiritual naturalistic approach to the concept of health. The approach is based on the processes of nature and the spiritual essence of man.

In the middle of the last century, a professor at Munich Technical University, Winfried Otto Schumann, found that the Earth and its ionosphere formed a giant resonator with a frequency of 8 hertz.

Long-running experiments were conducted in the United States (NASA) and Germany (M. Planck Institute), which found that Schumann waves were necessary to synchronize biological rhythms and the normal existence of everything alive on Earth.

Back in the 1950s, it was 20 that the intensity of Schumann 's resonance directly affected the highest nervous activity of man, as well as his intellectual abilities. Thanks to the resonance of Schumann waves of natural origin and standing brain waves, spiritual people whose brain hemispheres work in a synchronous rhythm have a healthy state. Science confirmed this experimentally. Dr. Robert Becker measured the brain waves of many spiritual healthy people. He found that they all have the same frequencies - 8 $\mathrm{Hz}$, regardless of their religious and spiritual traditions, and are synchronized with Schumann waves in both frequency and phase. Healthy people have a balanced psyche and resonance of cells in the biopolis at a vibration frequency of 8 hertz.

Human health is a psychophysiological state with balanced psyche and functioning of the organism at the electromagnetic frequency of cells 8 hertz and wavelength 8 meters in resonance mode in environmentally clean internal and environmental environment.

Human life has a spiritual nature based on spiritual processes. Spiritual processes of human activity and society are closely connected. They will help to acquire and preserve the health of mankind on a global scale. The spiritual infrastructure of society has a global and determinative impact on everyone's health. There is a global relationship between a person's spiritual processes and his physical health. Spiritual quality, like physical quality, is amenable to training. From spiritual state to healthy state - much faster. The relationship between the spiritual processes of man and his physical health, as well as the state of the whole society, is fundamental.

At the end of the last century, the scientific world was stirred by the results of experiments of Japanese scientist Masaru Emoto. Masaru Emoto 's experiments conclusively prove that the spiritual word has a healthy effect on humans and living nature.

Supports the healthy state of man spiritual mental energy, which is generated by the spiritual way of thought, ethical way of words, good desires, healthy way of life in ecological pure environment, spiritual connections with society, love for visible and invisible environment. By accumulating spiritual mental energy, man increases the health of creative workability.

Based on the spiritual-naturalistic approach to the concept of health, consider the natural conditions and activities of the transition to a healthy lifestyle.

The pure environment of the body is one of the necessary conditions for wave resonance of cells. Cleanliness is a guarantee of health. Pure environment of organism at anatomical and physiological level is achieved by hygienic and endoecological actions and healthy nutrition. Formation of pure environment of organism at energy level is achieved by communication with environmentally friendly nature: absorption of enzymes-enzymes of light energy and vibrations of plant world. The body's energy clean environment is preserved by an environmentally friendly environment, listening to harmonious music and freeing from negative energy by water procedures in the shower or bath, as well as in the bath, at sea or lake.

Psyche balancing is also a prerequisite for wave resonance of healthy cells. Balancing of psyche and formation of healthy state is carried out by spiritual useful actions. The development of the ability to perform spiritual actions and communication with righteous peaceful good thoughts and desires creates a natural need and habit of getting rid of harmful passions, forming mental health.

In order to maintain a healthy state, skills are acquired, first, by turning useful actions into useful habits by emotional fixation in various home, social and natural conditions. Secondly, coordination with the daily natural cycle of life rhythm in social, natural and home conditions to preserve the holistic healthy functioning of the body. Third, complex daily preservation of healthy state at spiritual, energy, physiological and anatomical levels in various home, natural and social conditions based on the system of cellular selfhealing. The skills of comprehensive daily healthy state preservation develop a habit of maintaining a holistic healthy state during each day. Fourth, frequency resonance diagnosis 
of a healthy condition. The body's weekly diagnosis skills help control a healthy condition.

Accumulation of healthy lifestyle experience is carried out by health saving skills in various household, social and natural seasonal conditions (spring, summer, autumn and winter). Seasonal preservation of balanced psyche and provision of holistic healthy functioning of organism in summer, autumn, winter, spring is carried out on the basis of system of cellular self-healing. The accumulation of experience of complex coordination of social healthy life activity with the annual natural cycle at spiritual, energy, physiological and anatomical levels is carried out in various domestic, natural and social conditions. Complex coordination of social healthy life activity with seasonal natural cycles accumulates experience to maintain a healthy state during the year. The habit of periodically diagnosing the body helps to control and maintain a healthy state for a year.

The family tradition of a healthy lifestyle helps maintain a healthy state during the year by family members and creates a healthy family environment. The cultural public tradition of a healthy lifestyle helps motivate citizens, achieve and maintain a healthy condition and lead a healthy lifestyle during the year and creates a healthy public environment. Cultural family and social tradition of healthy lifestyle plays an important role in mastering natural qualitative transition to healthy life

It is necessary to conduct spiritual education to achieve global healthy well-being and to build public health infrastructure on the basis of a healthy lifestyle, as a health sector to solve problems of demography, increase healthy longevity of the population, formation of a healthy labor human resource and a healthy nation.

\section{Conclusion}

South Korea's health and public administration system was able to quickly protect the population from COVID-19 without the imposition of emergency measures. Unfortunately, other countries at that time showed little vision, willingness and managerial will to protect the population from COVID-19. This now requires great costs, extraordinary measures and leads to great casualties. Autonomous infections of people with coronavirus in different countries confirm the natural origin of it. The reason for its appearance is the spiritual state of society. The spiritual level of humanity is falling. Harmful passions take a person away from normal life. The pernicious passion of one person breeds it in other people. The accumulated harmful passions of mankind according to spiritual laws in 2020 brought on it coronavirus. He suspended the destructive life of mankind and spread people around their corners to think about their lives and change them. The creator made people free to improve normal life according to spiritual laws. Religious denominations must teach their people to live by them. Spiritual processes are therefore important during the pandemic. Now, if humanity all over the world stands to pray for repentance and forgiveness of sins, God will show mercy and the pandemic will cease, as God showed mercy in the history of mankind in such situations [17].

The health system in public spaces needs to significantly improve the quality of sanitation and monitor the environment [6], as well as improve the hygiene and endoecology of citizens.

In conditions of self-isolation do not accumulate stress and excess weight to sick people. Constant stress can harm more than any virus. For now, sanitation, hygiene, endoecology, environment ecology, social distance, self-isolation, population testing, increased security and healthy spiritual lifestyle remain the main means of combating the spread of coronavirus.

In order to neutralize coronavirus promptly and effectively, it is necessary to separate the sources of infection, ways and mechanisms of its distribution in nature. Medicine does not yet have an understanding of how to determine it.

\section{References}

[1] E. G. Bryndin, I. E. Bryndina. Sanatorium Rehabilitation of the Population by the Healthy Lifestyle. International journal "Rehabilitation Sciences", Volume 2, Issue 2. USA. 2017. P. 35-40.

[2] Bryndin E. G., Bryndina I. E. Normalization of Psyche by Healthy Lifestyle of Various Groups of the Population. American Journal of Applied Psychology. V. 6, № 4. 2017, Pages: 51-56.

[3] E. G. Bryndin, I. E. Bryndina. Formation of Public Health Care on Basis of Healthy Lifestyle. International Journal of Psychological and Brain Sciences. Vol. 2, No. 3, 2017, pp. 6368.

[4] Bryndin E. G., Bryndina I. E. Natural Measures of Normalization of Vital Systems of the Person for Maintaining of the Healthy State. International Physical Medicine \& Rehabilitation Journal. V. 3 Issue 1. 2018. 8 pages. URL: $\mathrm{http}: / /$ medcraveonline.com/IPMRJ/IPMRJ-03-00069.php

[5] Bryndin E. G. Healthy lifestyle basis of maintaining health. Germany: LAMBERT Academic Publishing. 2018. 230 c.

[6] Evgeniy Bryndin. Development of living floor spaces on the basis of ecological economic and social programs. $J$. Resources and Environmental Economics. V. 1, N. 1.2018. P. $1-8$.

[7] Bryndin E. G., Bryndina I. E. Hygiene and Endoecology, Light Bioenergy and Natural Ecology, Balanced Mentality and Spiritual Life as Criterion of Health. Innovative Journal of Medical and Health Science. Vol 9, Iss 2, 299-306. 2019.

[8] Evgeniy Bryndin, Irina Bryndina. Natural Science Approach to Determination of Health and Formation of Healthy Lifestyle. ACTA SCIENTIFIC MEDICAL SCIENCES JOURNAL. Vol. 3, Issue 1. 2019. P. 26-37.

[9] Evgeniy Bryndin, Irina Bryndina. Development of Health Care on Basis of Healthy Lifestyle for Forming Future Medicine of Longevity. Acta Scientific Medical Sciences 3.5 (2019): 35-41. 
[10] Evgeniy Bryndin, Irina Bryndina. International Public Health Care on Basis Healthy Lifestyle. Asian Journal of Medical Science Research \& Review, Volume 1, Issue 2. 2019. Pages: 88-96.

[11] Bryndin E, Bryndina I. Training of Healthy Lifestyle in Educational Schools. Asclepius Medical Case Reports 2019; 2 (1): 1-3.

[12] Bryndin E. G., Bryndina I. E. Health Maintenance by Balanced Psyche, Spiritual Life, Hygiene, Endoecology and Ecological Nature. Research and Reviews on Healthcare: Open Access Journal, V. 4, № 1. 2019. Pages 322-328.

[13] Bryndin E. G. Bryndina I. E., Putmakov A. N. Enhanced action of the Person by Healthy Lifestyle and Correction of the Biofield by the Tomography Method. Journal of Medical
Review. ISSN (Online): 2589-9074, ISSN (Print): 25899066. 2019. Pages: 286-292.

[14] Evgeniy Bryndin, Irina Bryndina. Supporting Technology of Vigorous Activity by Normalization of Biofield and by Healthy Lifestyle. Journal of Integral Sciences, 2019, Vol. 2, Issue 2. Pages: 1-9.

[15] Evgeniy Bryndin, Irina Bryndina. Normalization of Psyche of the Motivated Population by Healthy Lifestyle. Lupine Online Journal Medical Sciences 4 (2) - 2019. Pages: 364-367.

[16] Evgeniy Bryndin. Self Healing of Healthy Condition at Cellular Level. Medical Case Reports and Reviews, Volume 3, London. 2020. Pages: 1-4.

[17] Bible. GmbH West Germany: Christlicher Verlag. 1991. 1210 pages. 